\title{
COVID-19 MÕJU LIIVI KEELE OMANDAMISE VÕIMALUSTELE ${ }^{1}$
}

\author{
GUNTA KL,AVA
}

\begin{abstract}
Annotatsioon. Liivi keele olukord tänapäeval näitab, et Covid-19 pandeemia on kõigele vaatamata pakkunud ka positiivset ning loonud võimalusi keeleõppeks ja ohustatud keelte säilitamiseks. Võimalik, et just pandeemia tõttu tekkinud olukord on soodustanud liivi keele säilitamist ning toonud pöörde arusaamades selle rollist ja funktsioonist terves ühiskonnas. See kinnitab kogukonnale ja ka laiemale üldsusele, et hoolimata väikesest oskajate ja kõnelejate arvust väärib liivi keel kõiki võimalusi, mis on kättesaadavad mis tahes teistele keeltele ja mida ei toeta mitte ainult tänapäeva (digi)tehnoloogia, vaid ka keelte lingvistilise elujõulisuse ja omandamise teoreetilised käsitlused. Artiklis vaadeldavad Covid-19 pandeemia mõjul tehtud sammud liivi keele populariseerimiseks ja õpetamiseks, sh Läti Ülikooli liivi instituudi korraldatud üritused, toetuvad uusimatele keeleõppe teooriatele ja meetoditele ning mitmekesise teabematerjali koostamise põhimõtetele. Ilmneb, et paindlik lähenemine keerulises olukorras ja loovad lahendused võivad ka väikesele keelele tagada keelte konkurentsis võrdväärse olukorra.
\end{abstract}

Võtmesõnad: ohustatud keeled, keel ja kultuur, keeleressursid, keeleõpe, keele omandamine, liivi keel, Covid-19

\section{Sissejuhatus}

Aasta 2020 jääb maailma mällu kui koroonaviiruse pandeemia aasta. Kõigis riikides tõi see kaasa kokkusaamise, liikumise ja avalike ürituste piirangud, mis puudutasid kõiki ühiskonnakihte ja -protsesse. Pandeemiast tingitud piirangutel polnud siiski ainult negatiivne mõju. Nii näitas pandeemiaolukord, et digitaalsed ja kaudlahendused pole mitte ainult mugavuse küsimus, vaid need on igapäevaselt vajalikud kõigil elualadel.

\footnotetext{
Artikli valmimist on toetatud järeldoktorantuuri projektist „Euroopa keeleõppe raamdokumendi rakendamine liivi keelele: uus võimalus ohustatud keelte jaoks“ (nr 1.1.1.2/VIAA/3/19/527). Artikli valmimisele aitas kaasa TTÜ veebipõhine kõnetuvastus (Alumäe jt 2018).
} 
Samuti sundis pandeemiaolukorra saabumine üleöö läbi mõtlema olemasolevaid tegevusi, otsima uusi võimalusi ja lahendusi, et argipäev saaks kriisioludes jätkuda. Pandeemiaaeg on toonud kaasa muutusi ka keelte taaselustamise alal, mida pidevalt mõjutavad eri tegurid.

Loomulikult mõjutas pandeemia juba niigi habrast liivi keele ja selle taaselustamise olukorda: võimalusi kokku saada, üritusi korraldada ja keelt kasutada ning õppida. Saabunud pandeemiaoludes tuli otsida uusi võimalusi laiendada liivi keele kasutusalasid ja toetada selle omandamist. Mõeldes kriitiliselt ohustatud keeltele, mille hulka kuulub ka liivi keel, ja võimalustele selliseid keeli taaselustada, mis on keerukas, aega ja ressursse nõudev protsess, on iga samm ülimalt oluline, sõltumata selle ulatusest, ning iga sellise sammu mõju saab hinnata vaid tagantjärele.

Vaadates tagasi pandeemia-aastale, võib öelda, et liivi keel on sellest väljunud sootuks tugevamana. See on osutunud võimalikuks tänu nii varasematele tegevustele liivi keele säilitamise, arendamise ja populariseerimise alal, mida pandeemia ajal täiendati ja jätkati, kui ka uutele võimalustele ja lahendustele, mis loodi just viimase aasta jooksul. Nendes tegevustes osales aktiivselt ka Läti Ülikooli liivi instituut, mille üks ülesanne on aidata kaasa liivi keele säilitamisele.

Artiklis antakse ülevaade koroonapandeemiaga seotud tähelepanekutest, kogemustest, algatustest ja järeldustest, pidades silmas liivi keele säilitamist ja populariseerimist. Ühtlasi kirjeldatakse mõningaid muutusi selle kogu ühiskonna ja ka liivi keele jaoks keerulisel, kuid ka huvitaval ja uuenduslikul kriisiperioodil, hinnates selle jäetud jälgi liivi keele püsimisse.

\section{Liivi keele hetkeolukord}

12. sajandi paiku elasid liivlased suurel alal tänapäeva Läti territooriumil, sealhulgas praeguse pealinna Riia ümbruses. Sajandite jooksul sulandusid liivlased kokku naaberhõimudega, osaledes tänapäeva läti rahvuse kujundamises, mille tulemusena liivi keele oskajate arv pidevalt vähenes. Siiski on liivi keel suutnud ellu jääda, säilides kõige püsivamalt omal ajal suletud ja perifeersel alal Kuramaa poolsaare põhjaosas, mida nimetatakse ka Liivi rannaks. (Ernštreits 2020a)

Alates 19. sajandi keskpaigast ja eriti 20. sajandi jooksul halvenes liivi keele olukord tunduvalt. Mõlemad maailmasõjad ja neile järgnenud 
Nõukogude okupatsioon, mis muutis Liivi ranna rindejooneks, hävitasid viimase liivlaste kompaktselt asustatud areaali Kuramaal ning sundisid liivlasi suunduma tööotsinguile üle Läti. Peamiselt asuti elama pealinna Riiga, aga ka Ventspilsi, mis on Liivi rannale lähim Läti linn. Liivi keele olukord muutus radikaalselt, keele edasiandmise protsess peatus peaaegu täielikult. (Blumberga 2013: 173, 190)

Kuigi liivi keele oskajaid pole viimase kahesaja aasta jooksul kunagi olnud palju - 19. sajandi keskel 2500 (Wiedemann 1861: XI), 20. sajandi esimesel poolel umbes 1500 (Mežs 2000: 81; Blumberga 2013: 184) -, on liivi keele rääkijate arv tänapäeval kriitiliselt vähenenud ning selles keeles suudab suhelda vaid umbes kakskümmend inimest kogu maailmas (Livones 2). 2011. aasta rahvaloenduse andmetel on Lätis registreeritud liivlaste arv 250 (Census 2011). Seetõttu on liivi keel kantud UNESCO ohustatud keelte nimekirja kriitiliselt ohustatud keelena ning see on tänapäeval kõige ohustatum keel Euroopa Liidus.

Et lahendada keele oskajate vähenemise ja keele edasiandmise peatumise probleemi, alustati juba 1970. aastatel tööd liivi keelepesade loomisega väljaspool liivlaste ajalooliselt asustatud ala. Sellisteks keelepesadeks kujunesid 1972. aastal Riias ja Ventspilsis loodud liivi lauluansamblid Līvlizt ja Kāndla (Blumberga 2013: 191). Kui Läti sai tagasi oma iseseisvuse, vähenes eri põhjustel nende ansamblite tähtsus, kuid jätkuvalt otsiti võimalusi, kuidas toetada liivi keele edasiandmist.

1988. aastal algasid katsed õpetada liivi keelt vabaainena eri kursustel. Alguses olid sellised kursused üsna populaarsed, kuid ajapikku nende tegevus suikus ning juba mõne aasta pärast katkes pea täielikult. Selle peamisteks põhjusteks olid kursustel osalejate erinev teadmiste tase, osalejate vanuselised erinevused, vähene liivlaste arv ja asumine eri elukohtades, mis mõjutas võimalusi komplekteerida keeleõppe gruppe samal tasemel osalejatest. Samuti oli puudus kvalifitseeritud õpetajatest. Nii muutusid keelekursused rohkem liivi kogukonna rühmade kokkutulekuteks, millel oli küll suur tähtsus kogukonna ühtekuuluvuse tugevdamisel, kuid millel puudus arvestatav mõju keele omandamisele või edasiandmisele. (Ernštreits 2016: 264)

1990ndatel toimus ka teisi üritusi, millega sooviti hoida liivi kogukonna ühtsust, tagada keele edasiandmine ja edendada selle kasutamist. 1989. aastal tähistati Irēl (läti Mazirbe) 1939. aastal avatud ja liivlaste kasutuses vaid lühikest aega olnud Liivi rahvamaja 50 aasta juubelit ning 
algatati liivi pühade traditsioon, mis on tänapäeval liivi kogukonna elus aasta tähtsaim sündmus. Need augustikuu esimesel laupäeval toimuvad pühad hõlmavad kõiki liivi kultuuriruumi elemente, mis on seotud liivi keele ja kultuuri edendamisega. Pühad on ka liivi kogukonna ja liivi keele oskajate ühiseks ainsaks regulaarseks kohtumiskohaks. (Ernštreits 2019: 106)

1992. aasta suvel alustas tegevust liivi laste ja noorte suvekool Mierlinkizt (Merelinnukesed). Suvekoolis osalejate ette valmistatud liivikeelsed etteasted on traditsiooniliseks pühade osaks. Seitsme kuni kümne päeva jooksul omandatakse suvekoolis algteadmisi liivi keelest ja kultuurist, mis teenivad peamiselt kogukonna identiteedi ülalpidamise vajadusi (Kḷava 2020: 22). Seda ülesannet täidab suvekool edukalt, mida näitab ka suur huvi suvekoolis osalemise vastu, vaatamata sellele, et osalemise eest tasuvad tavaliselt osalejad ise. Samuti on oluline suvekooli suur kasvandike arv, sest ka suureks sirgudes toetavad nad liivi vaimse pärandi säilitamist. Kokkuvõtvalt võib öelda, et see suvekool on olnud siiani ainus toimiv võimalus liivi keele õppimiseks ja praktiseerimiseks, sest liivi keele omandamise võimalusi Läti üldhariduskoolides ei ole, olenemata Läti seadustest (riigikeele seadus, seadus „Läti rahvuslike ja etniliste rühmade vabast arengust ja õigusest kultuuriautonoomiale“ jt) ja rahvusvahelistest dokumentidest (ÜRO põlisrahvaste õiguste deklaratsioon jt).

Peale juba kirjeldatud liivi vaimse kultuuripärandi säilitamise ja populariseerimise põhitegevuste toimub ka mitmesuguseid regulaarseid ettevõtmisi (Ernštreits 2019: 106): kogu Lätis tegutseb pidevalt enam kui kaheksa liivi muusikaühendust, infot jagatakse sotsiaalvõrgustike gruppide ja veebilehtede (Livones.net, Līvõ kēl, jm) kaudu, toimuvad üritused ning liivi keele rääkijate kokkusaamised. Liivi keele uurimise, keeleallikate loomise ja väljaandmise nimel tehakse pidevat tööd peamiselt Läti Ülikooli liivi instituudis ning Tartu Ülikooli eesti ja üldkeeleteaduse instituudis. Nendel tegevustel on keele õppimisel küll teoreetiliselt tähtis, kuid praktiliselt passiivne roll.

Pandeemiast tingitud ebaselgus tuleviku suhtes mõjutas kõigi eespool loetletud ürituste ettevalmistamist ja toimumist. Samas on võimalik, et just pandeemiast tingitud piirangud ja ümberkorraldused ühiskonnas motiveerisid liivi keele pärandi säilitamisel ja edasiandmisel välja mõtlema uusi lahendusi. Samuti aitas see parandada juba olemasolevate tegevuste efektiivsust ja kvaliteeti. 


\section{Seitse liivi keele tundi}

2020. aasta kevadel, kui kehtestati esimesed pandeemiaga seotud piirangud, hakkasid paljud asjad toimuma kaugteel. Üks nendest oli üldhariduskoolide õpe. Kuna selline olukord oli esmakordne, ilmnes, et kaugõpingute jaoks puuduvad sobilikud lahendused. Sellepärast valmis Läti haridus- ja teadusministeeriumi algatusel väga lühikese aja jooksul platvorm tavaklase.lv ('sinu klass'). Ajavahemikus aprillist maini oli televisiooni- ja veebikeskkonnas võimalik omandada 1.-12. klassini eri õppeaineid. Aineid pakuti 20-minutiliste staatiliselt filmitud koolitundide kujul. Õige pea muutus see platvorm väga populaarseks - 2020. aasta kevadel oli seda kokku vaadatud enam kui 500000 korda (LSM 2020).

Teiste ainete kõrval pakkus haridus- ja teadusministeerium võimalust kaasata veebiplatvormi eraldi ainena liivi keele tunde põhikooli 5.-9. klassile ja keskkooli 10.-12. klassile. See oli esimene kord, kui Läti üldhariduskoolide õppekava võimaldas omandada põhiteadmisi liivi keelest (Livones 1). Kavandatava teostamiseks võeti ühendust Läti Ülikooli liivi instituudiga, mille uurijad kaasasid ka liivi kogukonna esindajaid ja lõid veebiplatvormi jaoks seitse õppetundi. Õppetundidest sai Läti Ülikooli liivi instituudi eraldi projekt: online-saadete sari. Seitse liivi keele tundi (,,Seis līvõ kīel stuṇ,̣õ / 7 lībiešu valodas stundas“") on avalikult kättesaadavad Läti Ülikooli liivi instituudi YouTube'i kanalil (LU LI YouTube). Peab märkima, et aeg alates ideest kuni esimese tunni lindistuseni oli väga lühike (vähem kui nädal). Arvestada tuleb ka sellega, et senini puudus liivi keele tarbeks ja kindla sihtrühma jaoks mõeldud keeleõppe metoodika, mis tugineks keele omandamise teooriale (vt nt Mayo jt 2013; Okamura, Toru 2020).

See, et liivi keelega sooviti jõuda iga läti õpilaseni, sõltumata tema elukohast, teadmistest liivlaste kohta ja seosest nendega, määras suuresti ka loodud tundide sisu ja vormi. Nimelt oli esimestes tundides vaja õpetada mitte üksnes keele põhialuseid, vaid anda ka põhiteadmisi sellest, kes on liivlased, milline on nende roll Lätis, milline on liivi keel jne. Samal ajal oli aga vaja pakkuda esmaseid teadmisi liivi keelest. Ettenähtud tundide maht, kokku 140 minutit ehk 2,3 tundi, on ülimalt väike selleks, et omandada keelt või isegi selle põhialuseid. Näiteks standardse algaja keeletaseme (CEFRi järgi A1) omandamiseks planeeritav aeg varieerub vähemalt sajast kahesaja tunnini, sõltuvalt kõigist nendest teguritest, mis keele omandamist mõjutavad (Experience 2018: 218). Eespool nimetatu 
määras ka tunnikava: tunni teemade kaudu, mis olid sobitatud algaja tasemega, pakuti vaatajaile ka infot liivlaste, liivi keele, kultuuri ja ajaloo kohta. Igasse tundi kaasati ka liivlasi.

Paraku ei sobinud kavandatud keeleõppeks platvormi tavaklase.lv üldine formaat, kus tunde filmiti staatiliselt, montaaživõimalusteta, näidates klassiruumis oma ainet õpetavat õpetajat. Selline formaat sobib ehk argipäeval koolis omandatavate ainete jaoks, kuid mitte kavandatavate liivi keele tundide võimalikult täiuslikuks elluviimiseks. Seepärast paluti appi liivi kogukonna esindajad ja otsiti viise, kuidas 20 minuti pikkuses tunnis edastada visuaalselt kvaliteetses formaadis nii planeeritud sisu kui ka anda teavet liivlaste kohta. Tundide filmimisse kaasati professionaalne liivi päritolu Läti Televisiooni ajakirjanik, režissöör ja produtsent Dāvids Ernštreits.

Üllatav, aga üks pandeemiast tingitud positiivne mõju nii Liivi ranna kui ka liivlaste ajaloolise ala jaoks oli see, et liivi keele tundide filmimise ajal 2020. aasta kevadel võis rannas kohata taas liivlasi. Paljud, kes talvel Liivi rannas ei ela, olid pandeemia ajal tulnud liivi küladesse isolatsiooni ning pärast pikka aega oli külades lõpuks ka madalhooajal liivlasi ja nende järeltulijaid. Üks neist oli ka Dāvids Ernštreits. See loomulikult kergendas tundide filmimist, mis toimus peamiselt just Liivi rannas.

Õppetundide loomisel tuli arvestada nii tundide mahtu kui ka juba etteaimatavat üldiste teadmiste puudumist. Samas aitasid neid raskusi ületada liivi kogukonna esindajate aktiivne osalemine ja videoformaadi võimalused, näiteks video uuesti kasutamine eri siht- ja vanuserühmade jaoks. Tunnikavade väljatöötamine vastavalt formaadi nõuetele põhines multimeediaõppe kognitiivsel teoorial (vt Mayer, Moreno 2003), et videotunnid moodustaksid õppeprotsessi tõhusa osa ning oleksid heaks teabeallikaks kasutajatele, kes on huvitatud ainult ülevaate saamisest liivlaste kohta. See eeldas muu hulgas ka teabe selget esitamist, kasutades võimalikult väheseid teabeüksusi. Tundide loomise ajal oli oluline ka arusaam sellest, et sellise auditooriumini jõudmine ja meedia kasutamine on liivi keele jaoks suurepärane, uudne, esimene ja võib-olla isegi viimane võimalus. Tundide väljatöötajatel oli soov luua nii visuaalselt kui ka sisu poolest struktureeritud ja kvaliteetne toode, mida saaks kasutada pikka aega, vähemalt viie kuni kümne aasta vältel.

Seega kujundasid liivi keele tundide eesmärki ja saavutatavat tulemust kaks tegurit: põhiinfo andmine liivi keele, kultuuri ja ajaloo kohta ning 
pilk liivi keele põhialustele. Kasutades L2 õpetamisel tuntud teemadest lähtuvat õppemetoodikat, valiti õpetamise aluseks seitse teemat, mida on iga L2 keele omandamisel kõige sagedamini kasutatud. Nende abil seoti kokku muu informatiivne materjal liivlastest, liivi kultuurist ja ajaloost. Igas tunnis leidus kaks tinglikku kihti - keel ja teabematerjal. Tundide teemad olid üles ehitatud selliselt:

- 1. tund - viisakusfraasid (keel) ning keele mitmekesisus ja selgitamine, kes on liivlased (teabematerjal);

- 2. tund - tähestik ja häälikud (keel), liivi traditsioonid ja liivlaste rahvakultuuris tuntuim kevadine kalendripüha - lindude äratamine (teabematerjal);

- 3. tund - värvide nimetused (keel) ning liivi sümbolid, lipp ja hümn (teabematerjal);

- 4. tund - liivi kohanimed (keel) ja Liivi rand (teabematerjal);

- 5. tund - perekonnaliikmete nimetused (keel) ning liivi keele murded ja uudissõnade loomine (teabematerjal);

- 6. tund - arvsõnad (keel) ja liivi keel sugulaskeelte peres (teabematerjal);

- 7. tund - liivi keele jäljed läti keeles (keel) ja liivlaste jäljed Lätis ning olulisemad sündmused tänapäeval (teabematerjal).

Kokkuvõtvalt võib öelda, et need seitse liivi keele tundi on minimaalne põhikursus neile, kel puuduvad liivlastest ja liivi keelest varasemad teadmised. Samal ajal pakuvad need tunnid nii üldist pilku keelelisele mitmekesisusele ja keelte väärtustele kui ka keelte seosele ühiskonnaga, mis mõjutab keelte endi arengut ja olukorda. See on iseäranis tähtis, võttes arvesse, et arusaam liivi keelest kui Läti põliskeelest ei ole Läti ühiskonnas endiselt piisavalt levinud.

Oluline on meenutada, et UNESCO kuulutas 2019. aasta rahvusvaheliseks põliskeelte aastaks, mil eriti rõhutati keele väärtust ja vajadust säilitada põliskeeli, mille sekka kuulub ka liivi keel. Arvestades probleemi päevakajalisust, on mõistetav põliskeelte aasta korraldajate ja kõigi kaasatud keelekogukondade soov kuulutada vahemik 2022-2032 rahvusvaheliseks põliskeelte aastakümneks (ÜRO 2019), mis on suur samm väikeste ja hääbuvate keelte jaoks. 2019. aastal osales Läti Ülikooli liivi instituut aktiivselt liivi keele populariseerimise üritustel nii Lätis kui ka mujal, et teavitada ühiskonda maailma keelte olukorrast ja iga keele väärtusest. 
Üks kõige rohkem külastatud virtuaalseid üritusi, mis kasvas välja 2019. aasta tegevustest, oli 2020. aasta emakeelepäev. 21. veebruari emakeelepäeva alustati Läti Ülikooli liivi instituudi korraldatud veebipõhise liivi keele tunniga, mida saab järelvaadata instituudi YouTube'i kanalilt. See esimene kogemus kinnitas, et tehnoloogia võimalusi, eriti ohustatud keelte puhul, on vaja kasutada võimalikult laialt. Liivi keele säilitamiseks ja kas või minimaalseks kasutuseks on see eriti tähtis, arvestades kogukonna hajali elukohti.

Ministeeriumi algatus ning liivi kogukonna ja laiema ühiskonna huvi esimese liivi keele tunni vastu pandeemia alguses kujundasid justkui juhuslikult aluse kavatsusele analüüsida keele omandamise vajadusi tänapäeva tehnoloogia pakutavates formaatides ning süvenenumalt mõelda liivi keele kohast ja funktsioonidest tänapäeva ühiskonnas.

Vajadusele laiendada liivi keele omandamise võimalusi eri tasemetele ja sihtrühmadele, kasutades tänapäeva tehnoloogilisi võimalusi, viitavad artikli autori järeldoktorantuuri projekti „Euroopa keeleõppe raamdokumendi rakendamine liivi keelele: uus võimalus ohustatud keelte jaoks“ (,Applying the Common European Framework of Reference for Languages to Livonian: A New Opportunity for Endangered Languages") käigus läbiviidud küsitluste ja intervjuude andmed. Põhjalikud intervjuud liivi keelt hästi kõnelevate inimestega (keeleoskuse tasemed B ja C) ning teiste liivi kogukonna liikmetega näitasid suurt huvi asjakohaste digitaalsete keelekasutuslahenduste vastu, mis võib pakkuda võimalusi ja lootust liivi keele kasutamiseks argipäevas ning keele edasiandmiseks nooremale põlvkonnale. Oluline on märkida, et küsitlustes osalejad kasutasid mõistet „keel arvutis“ erinevate digitaalsete keeleressursside tähenduses (alates sõnaraamatutest ja võimalusest kontrollida õiget sõnavormi kuni keelekorpuste, tekstide ja liivi keeles levinud teabe laiendatud kättesaadavuseni), samuti tähistasid nad sellega keeleõppes kasutatavaid digivahendeid.

Üks olulisimaid ülesandeid lähitulevikus on arendada liivi keele omandamise võimalusi, arvestades kõiki keeleõppega seotud aspekte. Selles töös on palju raskusi, mis tulenevad nn väikeste ja ohustatud keelte omandamisega seotud problemaatikast: õppematerjalide või nende kasutamise traditsiooni puudumine, pedagoogilise ettevalmistusega õpetajate puudumine ja nende ebapiisav keeleoskus, keele omandamise programmide ja keelekasutusvaldkondade puudumine, millega kaasneb ka 
vajadus uue terminoloogia järele, õppematerjalide loomise jaoks vajalike keelestandardite puudumine jms.

\section{4. Õppematerjalide hindamise tulemused}

Veel enne koroonaviiruse pandeemiat oli Läti Ülikooli liivi instituut arvestanud Läti koolide nõudlusega ning loonud umbes kahe tunni pikkuse õppeprogrammi liivlaste ja liivi keele tundmaõppimiseks. Instituudi uurijad on programmiga osalenud mitmetes Läti koolides ja õpetajate kokkutulekutel. Koolilaste ja õpetajate entusiasm ning osalemine nendes õppetundides annavad tunnistust sellest, et need teadmised on olulised mitte üksnes liivlastele ja nende järeltulijatele, vaid ka laiemale osale Läti ühiskonnast (Ernštreits 2020b: 19). Selle programmi struktuur ja kohandamine vastavalt õpilaste sihtrühmale, õpilaste külastamine Läti koolides ning programmi katsetamine liivi laste ja noorte suvekoolis Mierlinkizt olid seitsme videoformaadis liivi keele tunni väljatöötamisel suureks abiks.

2020. aastal hinnati filmitud õppetunde liivi laste ja noorte suvekoolis Mierlinkizt kahes rühmas vastavalt suvekooli traditsioonilisele õpilaste jagunemisele: üks rühm vanuses 6-11 aastat, teine 11-16 aastat. Suvekoolis osalevatel lastel, kes on liivlaste järeltulijad või muul moel liivlastega seotud, eriti vanematel õpilastel, on teatud eelteadmised nii liivi keelest kui ka liivi kultuurist ja ajaloost. Töötades suvekoolis osalejatega, võis aga näha, et loodud videotundide abil saab edukalt kujundada huvitavat ja loomingulist õppeprotsessi. See kinnitas mitte üksnes videotundide ja muu videomaterjali kasutuse efektiivsust õppeprotsessis, vaid ka juba varem instituudi teadurite täheldatud vajadust mitmekesisemate õppevormide järele.

Seitse videotundi töötati välja põhi- ja keskkooli vanuserühmale ning nende kasutamisel suvekoolis Mierlinkizt pandi tähele, et võimalikult kiiresti tuleb mõelda ka õppematerjalidele, mis sobiksid väiksematele koolilastele vanuserühmas 1.-4. klass. Seda kinnitab ka artikli autori järeldoktorantuuri projekti uuring, mille põhjal võis järeldada, et puudus on eriti väikelastele mõeldud materjalidest. Intervjuudes viitasid sellele ka suvekooli õpetajad ja teised liivi kogukonna esindajad. Leiti, et õppematerjalid peavad sobima vanuserühmale ja olema küllalt lihtsad, näiteks kergelt korratavad, riimuvad laulukesed ja visuaalselt atraktiivsed raamatud vastavate tekstidega. Sellised õppevahendid peavad olema 
ka elektroonilisel kujul ning kättesaadavad võimalikult laiale huviliste ringile. See innustas instituudi töötajaid pöörduma ka selle keeleõppijate sihtrühma poole, mille tulemusena sündis järgmine projekt - laulud liivi keele omandamiseks.

\section{Laulud liivi keele omandamiseks}

Uue projekti mõte tugineb vajadusele luua materjal, mis oleks, nagu juba eespool mainitud, laste jaoks kaasahaarav ja lihtne ning soodustaks keele õppimist ja keelenähtuste mõistmist. Nii töötati 2020. aasta lõpus Läti riikliku kultuurkapitali abil välja projekt „Laula kaasa ja õpi liivi keelt““ („Lōla īṇõ ja op līvõ kīeldõ / Dziedi līdzi un mācies lībiešu valodu“", Livones 3). Loodi liivi laulude sari, kaasates selleks taas liivlasi. Liivi keele kõnelejad Julgī Stalte (koos oma perega) ja Ulla Fraser lõid ja laulsid laule, Dāvids Ernštreits oma meeskonnaga tegi videod. Salaspilsi liivi koori Lōja juht Girts Gailītis laulis samuti laule sisse ning teisendas laulude meloodiad noodikirja. Läti Ülikooli liivi instituudi teadurid omakorda hindasid liivi keele kvaliteeti ja vastavust pedagoogilistele eesmärkidele. Ka see laulude sari on leitav Läti Ülikooli liivi instituudi YouTube'i kanalilt.

Laulude projekti eesmärk oli luua liivikeelseid laule keeleõppe jaoks tähtsatel teemadel, näiteks inimene, loodus, loomad, arvud ja sugulased. Laulud on mõeldud eelkõige lastele, kuid ka kõigile teistele huvilistele, et õppida ja säilitada liivi keelt, arvestades laulmise rolli ka keele omandamise protsessis. Laul ja laulmine on keele säilitamisel, hoidmisel ja omandamisel üks sotsiaalselt ja emotsionaalselt mõjusamaid kognitiivseid vahendeid. Laulu kaudu antakse edasi traditsioonilisi kultuuriväärtusi ja nende eripära, keele omandamise seisukohalt on aga eriti oluline laulu abil edastatud keeletunne, kõla ja rütm. Liivi keele õppijatel - lastel - ei ole seni olnud võimalust kasutada vanuserühmale vastavaid tekstuaalselt ja muusikaliselt sobivaid laule. Nagu näitavad ka uuringud, aitavad isegi täiskasvanute puhul just lihtsad ja kergesti meeles peetavad laulud kaasa keele häälduse omandamisele, mis on rääkimisoskuse aluseks. Laulud võimaldavad omandada ning meelde jätta ka leksikat, fraase jm, samuti õppida tundma rahvatraditsiooni ja maailmavaadet. (Ludke jt 2014)

Laulude autoritele polnud ülesanne kerge, sest neil ei tulnud mitte üksnes luua tänapäevaseid liivikeelseid laule, vaid panna neisse ka liivi keele loomulik kõla ning tagada selle ja ka grammatiliste vormide ning 
temaatiliselt olulise sõnavara kerge õpitavus, järgides samas ka hea heliteose loomise põhimõtteid. Ühtlasi tuli laulude loojatel meeles pidada, et kunstiteose põhiülesanne oli just keele omandamine, seega pidid kunstilised võtted ja meloodia olema allutatud laulu didaktilisele põhifunktsioonile, jättes mõnikord autorite loomingulise eneseväljenduse soovi tagaplaanile. Nii saab näiteks esimeses avaldatud laulus „Lēba“ („Leib“) teavet selle kohta, milline väärtus on leival, kuid ka õppida toiduainete nimetusi, tegusõnade tahtma ja sööma pööramist kõigis isikutes ning erinevate nimisõnade käänamist. Selleks, et õpetada liivi keele hääldamist, on oluline nii kuulda keelt kui ka näha inimese suu liikumist, mistõttu on režissöör pööranud filmimise käigus erilist tähelepanu lauljate lähiplaanidele. Keele õppimiseks loodud laulude ja nende videoformaadi loomine on toonud kaasa mitmekesiseid ülesandeid, mida tuli eesmärgi saavutamise nimel järgemööda lahendada.

\section{Uus kogemus ja järeldused}

2020. aasta pandeemiaolukord sundis inimesi kogu maailmas vähendama otsesuhtlust ja kontakte. Selle tulemusena kujunes aga veelgi tähtsamaks ja põhjendatumaks idee muuta keeled digitaalses ruumis eri eesmärkidel hõlpsamini kasutatavaks. Tundub, et vähemalt liivi keele säilitamist ja taaselustamist silmas pidades on just pandeemiaolukord kiirendanud neid protsesse, milleks kogukond ise oli juba valmis. Uut laadi õppevahendite loomiseks oleks ehk muul juhul olnud vaja palju rohkem aega ning nende lisaväärtus oleks olnud palju väiksem.

Koroonaviiruse aasta näitas, et oleme sammunud uude ajastusse, mil digi- ja kauglahendused, mis siiani olid justkui midagi eksklusiivset, on muutunud esmatarbeasjadeks ning äripäeva lahutamatuks osaks. Selliste uut tüüpi lahenduste kasutamine aitab hoida liivi keele keskkonda ja ületada neid probleeme, mida omal ajal (umbes pool sajandit varem) põhjustas ühtse liivi keeleareaali kaotamine. Sellised lahendused võimaldavad kiirendada ja efektiivsemaks muuta ka liivi keele taaselustamise protsessi ning isegi siis, kui keele taaselustamine mõnel põhjusel pole võimalik, aitavad need luua uusi ajastukohaseid kaasaegse liivi keele ja kultuuri näiteid.

Pandeemiaaeg tõestas, et ohustatud keelte õpe peab olema veel paindlikum ja uuenduslikum kui ehk nn suurte keelte puhul, kus paljud keele 
arenguprotsessid toimuvad justkui iseenesest. Et väikese kõnelejaskonnaga ohustatud keeled suudaksid tänapäevasel teabe ülekülluse ajastul ellu jääda ja maailmakeelte konkurentsis vastu pidada, on loomingulisus ja kohanemisvõime põhilisteks teguriteks pidevalt muutuvas olukorras. Ohustatud keelte jaoks on väga oluline suuta dünaamiliselt uute olukordadega sobituda, muuta puudusi voorusteks ning pidevalt otsida, näha ja kasutada uusi võimalusi.

Saavutatud tulemusi kokku võttes saab esile tuua mitu väärtuslikku tähelepanekut ja kogemust seoses liivi keele hoidmise ja taaselustamisega, mis võivad olla kasulikud iga ohustatud keele arendamisel. Arvestades iga väikese kõnelejaskonnaga keele jaoks aktuaalset ressursside nappuse probleemi, on esmajoones oluline tagada loodud materjalide võimalikult hea kvaliteet, et kõik loodavad keeleõppe vahendid kajastaksid hästi keelesüsteemile ja vaimule vastavat keelt. Ohustatud keeled ei saa võistelda digitaalselt kättesaadavate mis tahes liiki tekstide kvantiteedis suurte keeltega, millel on mahukad keeleressursid ja kus õpetamiseks kohaste keelenäidete valimisel võidakse lähtuda konkreetse vormi kasutussagedusest korpustes. Näiteks kui tekstides mõne kasutatud sõnavormi variantidest kaks on õiged ja kaheksa valed, ei saa me väikekeelte puhul automaatselt eeldada, et sagedamini kasutatav vorm on õige. See rõhutab ka iga ohustatud keele rääkija vastutust kasutada õiget keelt, hoolimata sellest, kui tervitatav on keeleteadja rollile pretendeeriva aktivisti soov luua kasvõi üks lause ja avaldada see oma sotsiaalvõrgustiku profiilis. Mõnikord võib vigaselt kirjutatud tekst tekitada väikekeelele suuremat ja jäävamat kahju, kui see oleks suure kõnelejaskonnaga keele puhul võimalik.

Kvalifitseeritud inimeste, keeleoskajate, raha jm nappus määrab suuresti ka vajaduse nende efektiivseks kasutamiseks ohustatud keele säilitamisel ja arendamisel. Mõlemad artiklis kirjeldatud projektid kaasavad ühiskonna esindajaid - nii neid, kes keelt oskavad, kui ka neid, kes on aktiivsed kogukonna liikmed, kultuuri hoidjad ja populariseerijad mõnel teisel alal - ning toovad seeläbi kahepoolset tulu. Ühelt poolt annavad nad panuse keele püsimisse ja arengusse, teiselt poolt on sellest kasu ka neile endile, sest neil on võimalik tegelda oma keele ja kultuuriga, viibida liivikeelses keskkonnas ja kasutada liivi keelt, milleks tänapäeval võimalusi napib või millel on üksnes sümboolne väärtus. Lõpuks, mis on ehk veelgi tähtsam - sellised uuenduslikud ettevõtmised võimaldavad näha, et liivlusel ja liivi keelel on samuti oma koht selles maailmas. 


\section{Kirjandus}

Alumäe, Tanel, Ottokar Tilk, Asadullah 2018. Advanced Rich Transcription System for Estonian Speech. Baltic HLT 2018.

Census 2011. Tautas skaitīšana 2011. Centrālā statistikas pārvalde. https://www. csb.gov.lv/lv/statistika/statistikas-temas/iedzivotaji/tautas-skaitisana/ tabulas/tsg11-06/latvijas-pastavigie-iedzivotaji-pec (15.06.2020).

Blumberga, Renāte 2013. Lībieši 19.-21. gadsimtā. - Lībieši. Vēsture, valoda un kultūra. Red. Renāte Blumberga, Tapio Mäkeläinen, Karl Pajusalu. Rīga: Līvõ Kultūr sidām, 169-204.

Ernštreits, Valts 2016. Livonian in recent years. - Eesti ja soome-ugri keeleteaduse ajakiri / The Journal of Estonian and Finno-Ugric Linguistics 7 (1), 257-274. https://doi.org/10.12697/jeful.2016.7.1.12

Ernštreits, Valts 2019. Lībiešu kultūrtelpa. / The Livonian cultural space. Nemateriālais kultūras mantojums Latvijā - Nacionālais saraksts. / Intangible Cultural Heritage in Latvia - National Inventory. Rīga: Latvijas Nacionālais kultūras centrs, 102-109.

Ernštreits, Valts 2020a. Lībiešu valoda. - Nacionālā enkciklopēdija. https:// enciklopedija.lv/skirklis/5259-1\%C4\%ABbie\%C5\%A1u-valoda (04.08.2020).

Ernštreits, Valts 2020b. Lībiešu institūta pirmie soḷi. - Līvlizt Āigastrōntõz / Lībiešu Gadagrāmata 2020. Rīga, 16-20.

Experience 2018. How Long Does it Take to Learn a Foreign Language. Experience Better Learning. Cambridge University Press. https://www. cambridge.org/elt/blog/wp-content/uploads/2018/10/How-long-does-ittake-to-learn-a-foreign-language.pdf (12.12.2020).

Kḷava, Gunta 2020. Lībiešu valodas apguve - vai neiespējamā misija? - Līvlizt Āigastrōntõz / Lībiešu Gadagrāmata 2020. Rīga, 21-24.

Livones 1 = Iespēja iepazît lībiešu valodu un kultūru TV projektā tavaklase.lv. http://www.livones.net/lv/norises/2020/iespeja-iepazit-libiesu-valoduun-kulturu-tv-projekta-tavaklase-lv (12.12.2020).

Livones $\mathbf{2}$ = Lībiešu valoda. http://www.livones.net/lv/valoda/?libiesu-valoda (15.06.2020).

Livones 3 = Dziedi līdzi un mācies lībiešu valodu! http://www.livones.net/lv/ norises/2020/dziedi-lidzi-un-macies-libiesu-valodu (04.01.2021).

LSM 2020 = Projektu «Tava klase» varētu turpināt arī normāla mācību režīma laikā. LSM.lv, 28. maijs, 2020. https://www.lsm.lv/raksts/zinas/latvija/ projektu-tava-klase-varetu-turpinat-ari-normala-macibu-rezima-laika. a361551/ (15.12.2020.)

Ludke, Karen M., Fernanda Ferreira, Katie Overy 2014. Singing can facilitate foreign language learning. - Memory \& Cognition 42, 41-52. https:// doi.org/10.3758/s13421-013-0342-5 
LU LI YouTube. https://www.youtube.com/channel/UC1EyUxE3iNJjJajBEP0GENA (02.01.2021.)

Mayer, Richard E., Roxana Moreno 2003. Nine ways to reduce cognitive load in multimedia learning. - Educational Psychologist 38 (1), 43-52. http:// dx.doi.org/10.1207/S15326985EP3801_6

Mayo, María del Pilar García, María Junkal Gutierrez Mangado, Maria Martínez Adrian 2013. Contemporary Approaches to Second Language Acquisition. John Benjamins Publishing Company. https://doi. org/10.1075/aals.9

Mežs, Ilmārs 2000. Jūrmalas ciemu iedzīvotāji 1935. gada tautas skaitīšanas uzskaites lapās. - Lībiešu gadagrāmata / Līvlizt āigastrōntõz 2000. Lībiešu krasts: Valsts īpaši aizsargājamā kultūrvēsturiskā teritorija "Lībiešu krasts", 76-85.

Okamura, Toru, Masumi Kai (eds.) 2020. Indigenous Language Acquisition, Maintenance, and Loss and Current Language Policies. IGI Global. 10.4018/978-1-7998-2959-1

ÜRO 2019 = United Nations General Assembly Resolution "Rights of indigenous peoples“. A/RES/74/135. https://undocs.org/en/A/RES/74/135 (02.01.2021).

Wiedemann, Ferdinand Johann 1861. Joh. Andreas Sjögren's Livische Grammatik nebst Sprachproben. - Joh. Andreas Sjögren's Gesammelte Schriften. Band II. Theil I. St. Petersburg.

Gunta Kḷava

Liivi instituut

Läti Ülikool

Kronvalda bulv. 4-220

LV-1010, Riia

gunta.klava@lu.lv 


\title{
The effect of Covid-19 on Livonian language learning pportunities
}

\author{
GUNTA KLAVA
}

This article examines several programmes created by the University of Latvia Livonian Institute promoting Livonian language learning which came about as a result of the circumstances of the Covid-19 pandemic. The value and role of specifically digital solutions increased across society during this period, becoming a standard part of every aspect of daily life.

Taking into account the reasons for the present Livonian language situation, it becomes clear that despite the overall seriousness of the circumstances created by the pandemic, there have also been certain positive developments for language learning and endangered language maintenance resulting from this situation. It may be that the pandemic situation prompted a change in perspective - among not only researchers but also society in general - on Livonian language preservation as well as its role and function. This shift confirmed and emphasised to the Livonian community as well as to broader society that Livonian - despite its small number of speakers - deserves the same opportunities available to every language and that these are offered not only by modern technology, but also by linguistic insights into language vitality and language acquisition theory. In this context, the two main Livonian language learning programmes prompted by the pandemic are discussed. These are: (1) the 7 online Livonian language lessons, which originally were developed as an instructional module for general education schools and were the first time in history when the opportunity to study Livonian was included in the school programme in Latvia; and (2) the next step in learning language basics, which grew out of this project - a series of songs written by Livonian authors intended for children and young people.

These Livonian language learning and popularisation initiatives - motivated by the circumstances of the Covid-19 pandemic - are grounded in new approaches and methods of language acquisition as well as other proven techniques for preparing educational materials. These initiatives show that in a difficult situation, a flexible approach and creative solutions can place even a small language on a more equal footing when competing with larger languages.

Keywords: endangered languages, language and culture, language resources, language learning, language acquisition, Livonian, Covid-19 